\title{
Efficacy of some disinfection methods on the microbial load of eggs and equipment of tilapia hatchery
}

T. F. Ismail, Samah E. Laban, Nada M. El-kabany, Mohga F. Badawy*

Department of Animal, Poultry and Environmental Hygiene,

Faculty of Veterinary Medicine, Cairo University;Giza, Egypt

Abstract

In fish hatcheries, high densities of eggs are maintained in incubators with microbial loads that vary from those in the natural habitat. Moreover, the accumulation of organic debris on tools used in the hatchery facility assists the spread of infectious diseases. This study was designed to evaluate the effect of different iodophor concentrations $(10,50,100$ and $150 \mathrm{ppm})$ for different contact times $(5,10$ and $15 \mathrm{~min})$ on total bacterial count (TBC) and total fungal count (TFC) and hence on the hatchability percentage of tilapia eggs. In addition, the effect of common salt $(\mathrm{NaCl})$, sunlight exposure, $1 \%$ Halamid $\AA, 1 \%$ Virkon $S \circledR$ and 3\% Aquazix ${ }^{\circledR}$ for contact times $(5,10$ and 15 min) in reducing TBC and TFC on hatchery equipment (buckets, nets and dishes)was also evaluated. Iodophor treatment at $10 \mathrm{ppm}$ for $15 \mathrm{~min}$ resulted in significant reduction of both TBC and TFC on tilapia eggs by $\geq 4 \log _{10}$ reductions but failed to achieve complete disinfection of egg surface. Conversely, $50 \mathrm{ppm}$ or higher iodophor concentrations did not display antimicrobial activity after all tested contact times. Hatchability percentage was insignificantly different between $0 \mathrm{ppm}(90 \%)$ and $10 \mathrm{ppm}(94 \%)$ of iodophor. However, $10 \mathrm{ppm}$ iodophor was significantly different (P < $0.05)$ from $50 \mathrm{ppm}(85 \%)$ and $100 \mathrm{ppm}(65 \%)$. At $150 \mathrm{ppm}$, there was no hatchability. After application of different disinfectants, limited to general bactericidal activity of $\geq 4 \log _{10}$ reduction was observed in common salt $(\mathrm{NaCl} 150$ $\mathrm{g} / 7$ liters) after $15 \mathrm{~min}$ in dishes only, sunlight exposure after $10 \mathrm{~min}$ in dishes onlyand $3 \%$ Aquazix after $15 \mathrm{~min}$ in all tools. Significant and $100 \% \log$ reduction of both TBC and TFC was observed in $1 \%$ Halamid $^{\circledR}$ after 10 min and $1 \%$ VirkonS $^{\circledR}$ after 15 min.

(Keywords: disinfection, fish, eggs, hatchability, equipment, iodophor and halamid)

\section{Introduction}

Egypt ranked $8^{\text {th }}$ position in leading aquaculture producing countries in the world with about 987 thousand tonnesaccording to FAO(2011). The development and expansion of a large number of tilapia hatcheries in Egypt supported the development aquaculture sectorSaleh, (2007). The mass-scale business of tilapia fry production includes the broodstock management, artificial egg incubation and larval rearing (Macintosh and Little, 1995). Bacterial infections are major causes of both egg losses and deformed fish larvae (Harboe et al. 1994). These losses are not attributed to obligate pathogenic bacteria, but rather to proliferation of opportunistic bacteria in the environment of intensive egg incubation (Skjermo and Vadstein 1999). The control of bacteria on fish eggs includesthe application of suitable surface chemicals disinfectantson fish eggs (Atanasov et al. 2011).Iodophorslink free iodine with a carriertomaintain the reactive nature of iodine (McDonnell \& Russell, 1999). Iodophors are effective for pathogen-specific egg disinfection (Yanong and ErlacherReid,2012), however little information about its activity for tilapia eggs disinfection is known. Good sanitary measurements play an important role in removing the organic debris. All equipment, surfaces and vehicles must be cleaned and disinfected within the aquaculture facility (Yanong and Erlacher-Reid, 2012). The choice of a suitable disinfectant is a key element of disinfection. Sunlight can be an effective disinfectant if given sufficient time and intensity(Danner and Merrill, 2006). "Chloramine T"orHalamid® is a disinfectant that attacks microbes through a process of oxidation, therefore they cannot build up a resistance to it. In addition, chloramine $\mathrm{T}$ is highly stable and remains active over an extended period of time(Edrisi et al.,2012).Virkon $\mathrm{S} \circledast$ (DuPont, USA) is effective at inactivating both enveloped and nonenveloped viruses (Eleraky et al.,2002).Aquazix ${ }^{\circledR}$ is a disinfectant based on hydrogen peroxide which has received attention for its control of several fish pathogens and is recommended as a general disinfectant in aquaculture (Avendano-Herrera et al., 2006).

This study was designed to assess the effect of iodophorontotal microbial load and onthe hatchability percentage of tilapia eggs.In addition,the effect of common salt $(\mathrm{NaCl})$, sunlight exposure, Halamid®, Virkon $S \AA$ and Aquazix ${ }^{\circledR}$ inreducing total microbial load on hatchery tools will also be evaluated. 


\section{Materials and Methods}

\section{Egg disinfection}

The experiment was carried out in a tilapia hatcheryatAl-FayoumProvince.The effect of different concentrations of iodophor on total microbial load and on hatchability percentage was performed accordingtoSubasinghe and Sommerville(1985) with some modifications. Different concentrations of Iodophor were prepared using distilled water $(10 \mathrm{ppm}, 50 \mathrm{ppm}$, $100 \mathrm{ppm}$ and $150 \mathrm{ppm})$. The prepared disinfectant concentrations were maintained in plastic containers at a temperature of $27 \pm 1^{\circ} \mathrm{C}$ for one hour before the treatment to raise its temperature to the egg incubation temperature.Tilapia eggs were removed from the mouth of brooding females within $15 \mathrm{hr}$ of spawning and were held in 5 funnels, each containing 100 eggs. Theneggs were exposed to the disinfectant concentrations 10, 50,100, 150 ppm placed in containers respectively and the last container was left without disinfectant as a control.At 5,10 and $15 \mathrm{~min}$ contact time, one gramegg sample was removed and homogenized in a screw capped vial containing $1 \mathrm{ml}$ sterile normal saline according to Jantrakajorn and Wongtavatchai (2015) then ten-fold serial dilutions were prepared.The total viable bacterial counts were estimated by spread plate method on plate count agar medium (Oxoid) and total viable fungal counts were estimated by spread plate method on Sabourad's dextrose agar (Oxoid) using methods described by APHA et al. (1998).After $15 \mathrm{~min}$, nets containing eggs were removed and washed by gentle agitation in distilled water.Then the eggs were incubated in their funnels with a closed recirculatory system. Temperature, $\mathrm{pH}$, dissolved oxygen, ammonia and nitrite were monitored throughout the experiment (Table 1). The number of hatched fry was counted within $12 \mathrm{hr}$ of hatching. The percentage hatchability of fertile eggs was calculated for each treatment.

\section{Equipment disinfection}

Different disinfectantswere used to reduce microbial contamination on buckets, nets and dishes(3 units per each) used in the hatchery. Disinfectants were diluted according to the manufacturer instructions. Dilution was made with tap water; $1 \% \operatorname{Halamid}^{\circledR}($ Axcentive, France), 1\%Virkon S (Dupont, USA) and 3\% Aquazix (BBZix, Spain).We also evaluated the effect of sunlight exposure and $\mathrm{NaCl}(150 \mathrm{~g} / 7$ liters).

Before application of each disinfectant, tools were swabbed with sterile cotton swabs moistened with sterile normal saline and sample wereobtained from an outlined squares using wire template $10 \times 10 \mathrm{~cm}$, according to Collins et al.(1991). Swabs were kept in sterile test tubes containing $5 \mathrm{ml}$ sterile physiological saline. Test tubes were transferred to laboratory in an ice box as soon as possibleandten-fold serial dilutions were prepared. Duplicate plate count agar plates(oxoid) and duplicateSabourad's dextrose agar (Oxoid) plates containing $0.05 \mathrm{mg}$ of chloramphenicol $/ \mathrm{ml}$ were inoculated each with $100 \mu \mathrm{l}$ from each dilution and total bacterial and total fungal counts were determined APHA et al. (1998).After application of each disinfectant, the tools were swabbed again as previously mentionedat 5,10 and 15 min contact times and total bacterial and total fungal counts, respectively. According to European Committee for Standardization (CEN), EN 13697-2001, bactericidal activity was defined as $\geq 4 \log _{10}$ reduction of organisms attached to a surface under examination.

\section{Statistical analysis}

Differences in total microbial counts in relation to the type and concentration of disinfectant and the time of contact were analyzed by SPSS version 20 (SPSS Inc., Chicago, IL, USA). Pearson Chi-Square, Two-way analysis of variance (ANOVA) and LSD test for post hoc comparison were used. The level of significance was set at $\mathrm{P}<0.05$.

\section{Results \\ Effect of iodophor on total microbial count and hatchability percentage of tilapia eggs}

Table (2) showedtotal microbial count for eggs before and after exposure to different concentrations of iodophor (10 ppm, $50 \mathrm{ppm}$, $100 \mathrm{ppm}$ and $150 \mathrm{ppm}$ ). Total bacterial count (TBC) for eggs before treatment was (7.18 \pm 0.86$) \log _{10}$ colony forming unit (CFU) /g.Iodophor concentration at $10 \mathrm{ppm}$ significantly $(\mathrm{P}<0.05)$ reduced $\mathrm{TBC}$ to (3.31 \pm 1.30$) \log _{10} \mathrm{CFU} / \mathrm{g}$ after $15 \mathrm{~min}$, while at 5 or 10 min contact time, insignificant reduction was recorded.At 50, 100 and $150 \mathrm{ppm}$, there was no significant difference in TBC after all tested contact times. .

Total fungal count (TFC) for eggs before treatment was $(5.63 \pm 1.87) \log _{10} \mathrm{CFU} / \mathrm{g}$. Log reduction in TFC was significantly $(\mathrm{P}<0.05)$ higher at $10 \mathrm{ppm}$ than 50, 100 and 150 ppm.Iodophor concentration at $10 \mathrm{ppm}$ significantly reduced TFC to $(0.69 \pm 0.00) \log _{10}$ CFU / g after $15 \mathrm{~min}$, while at 5 or $10 \mathrm{~min}$ contact time, insignificant reduction was 
recorded. At 50, 100 and $150 \mathrm{ppm}$, there was no significant difference in TFC after all tested contact times. Hatchability percentage was insignificantly different between $0 \mathrm{ppm}$ (90\%) and 10 ppm (94\%). However, 10 ppm iodophor was significantly different $(\mathrm{P}<$ $0.05)$ from $50 \mathrm{ppm}(85 \%)$ and $100 \mathrm{ppm}$ $(65 \%)$. At $150 \mathrm{ppm}$, there was no hatchability.

\section{Effect of some disinfectants on total microbial count of hatchery equipment}

Table (3) illustrates mean \pm SD of TBC $\left(\log _{10}\right.$ CFU / $\mathrm{cm}^{2}$ ) before and after exposure to different disinfectants for different contact times on some hatchery tools. Before disinfection, the average TBC was around $8.79 \pm 1.76,8.89 \pm 1.83$ and $8.81 \pm 1.83 \log _{10} \mathrm{CFU} / \mathrm{cm}^{2}$ for buckets, dishes and nets, respectively. After application of different disinfection methods, bactericidal activityof $\geq 4 \log _{10}$ reduction was observed in common salt ( $\mathrm{NaCl} 150 \mathrm{~g} / 7$ liters) after $15 \mathrm{~min}$ in dishes only, sunlight exposure after $10 \mathrm{~min}$ in dishes only, $1 \%$ Halamid $^{\circledR}$ after 5 min in all tools with $100 \% \log$ reduction after $10 \mathrm{~min}$ in all tools, $1 \%$ Virkon $\mathrm{s}^{\circledR}$ after $10 \mathrm{~min}$ in all tools with $100 \% \log$ reduction after $15 \mathrm{~min}$ in all tools, and $3 \%$ Aquazix after $15 \mathrm{~min}$ in all tools. Significant $\log$ reduction $(\mathrm{P}<0.05)$ was recorded for $1 \%$ Halamid $^{\circledR}$ after 10 min followed by $1 \%$ Virkon $\mathrm{s}^{\circledR}$ after 15 min. Table (4) illustrates mean \pm SD of TFC $\left(\log _{10}\right.$ CFU $\left./ \mathrm{cm}^{2}\right)$ before and after exposure to different disinfectants for different contact times on some hatchery tools. Before disinfection, the average TFC was around $4.43 \pm$ $0.78,4.63 \pm 0.83$ and $4.71 \pm 0.85 \log _{10}$ CFU / $\mathrm{cm}^{2}$ for buckets, dishes and nets, respectively. After application of different disinfection methods, significant fungicidal activity of $\geq 4$ $\log _{10}$ reduction $(\mathrm{P}<0.05)$ was observed in $1 \%$ Halamid $^{\circledR}$ and $1 \%$ Virkon $\mathrm{s}^{\circledR}$ after $10 \mathrm{~min}$ in all tools with $100 \% \log$ reduction. After $15 \mathrm{~min}$, all disinfectants showed $100 \%$ log reductionof TFC in all tools.

\section{Discussion}

In fish hatcheries, high densities of eggs are maintained in incubators with microbial loads that vary from those in the natural habitat. Disinfection of eggs aimed at eliminating or greatly diminishingpathogen transmission to different fish farms (Wagner et al. 2008).Iodine has proved itself as an efficient disinfectant against multiple fish pathogens (Wagner et al., 2010) and at the same time, it has showed low toxicity to fish eggs (Stuart et al., 2010). The results of this study showed that iodophortreatment at $10 \mathrm{ppm}$ for $15 \mathrm{~min}$ significantly reduced TBC and TFC of tilapia eggsby $\geq 4 \log _{10}$ reductionsbut failed to achieve complete disinfection of egg surface. Conversely, $50 \mathrm{ppm}$ or higher iodophorconcentrations did not display marked activity after all tested contact times.Similar results were reported by (Tendencia, 2001) who recorded that $(2.5-20 \mathrm{mg} / \mathrm{L})$ iodine, the lower concentrations of iodine was to be effective in reducing the total bacterial load of grouper eggs, Epinepheluscoioides, at both the cleavage and eyed stages. Also, Varner-Jeffreys et al. ( 2007) recorded that the minimal recommended concentration of active iodine for limiting fungus development is about $10 \mathrm{mg} \mathrm{dm}^{-3}$. On the contrary,(Stuart et al. 2010, Overton et al. 2010, Katharioset al. 2007, Peck et al. 2004) recorded that the most commonly used concentrations, which were thought to be efficient disinfectants, were $50-100 \mathrm{mg} \mathrm{dm}^{-3}$.

The effect of iodophore disinfection on hatchability percentage revealed insignificant improved hatchability $(\mathrm{P}>0.05)$ at $10 \mathrm{ppm}$ level. Though, the improvement at $10 \mathrm{ppm}$ level was significantly higher than that at 50 and 100 ppm level $(\mathrm{P}<0.05)$. In contrast, at $150 \mathrm{ppm}$ the hatchability was nil. These results were different from (Subasinghe and Sommerville, 1985) who reported that hatchability improvement at 50 and $100 \mathrm{ppm}$ level was significantly higher than that at $10 \mathrm{ppm}$ level. Meanwhile, we agree with (Subasinghe and Sommerville, 1985) whoobserved no hatchability at iodine concentrations higher than $100 \mathrm{ppm}$. It can be concluded that although hatchability percentage between control and $10 \mathrm{ppm}$ has no significance different but the significant decrease in total bacterial count and total fungal count recommend the use of disinfectant to prevent the vertical transmission of pathogens from the parent stock to the progeny and to prevent horizontal transmission from the egg facility to the rearing facility.

Sanitation is the backbone of fish biosecurity system in modern aquaculture. The accumulation of organic debris in the aquaculture facility assists the spread of a number of infectious diseases.In this study, the effect of some disinfection methods on hatchery tools was evaluated. Common salt, sun exposure and Aquazix though displayed limited to general antimicrobial action, failed to completely remove surface microbial loads. Significant and $100 \% \log _{10}$ reduction of heterotrophic viable 
bacterial and fungal counts, from the surface of buckets, nets and dishes used in the hatchery facility, was reached by the use of $1 \%$ Halamid $^{\circledR}$ (Chloramine $\mathrm{T}$ ) for $10 \mathrm{~min}$ and $1 \%$ Virkon $\mathrm{s}^{\circledR}$ for $15 \mathrm{~min}$.These results agreed with(Güngör and Yurudu, 2015) who reported thatafter the application of Chloramine $\mathrm{T}$, the heterotrophic bacterial counts on the surfaces were decreased. Log reduction in total bacterial count after application of $1 \%$ virkon $\mathrm{S}$ on buckets, dishes and nets was > $4 \log$ after $10 \mathrm{~min}$ and $100 \% \log$ reduction was aceived after $15 \mathrm{~min}$. This result agreed with Elerakyet al. (2002) who reported that manufacturer's guidelines for Virkon $\mathrm{S}{ }^{\circledR}$ recommend a $1.0 \%$ solution for disinfecting equipment with a $10 \mathrm{~min}$ contact time. After application of Aquazix, the count was reduced after disinfection to be(4.38 - 4.61) $\log _{10} \mathrm{CFU} /$ $\mathrm{cm}^{2}$ after $15 \mathrm{~min}$.Aquazixresulted in> $4 \log _{10}$ reduction in the cultivable heterotrophic bacteria on buckets, dishes and nets after $15 \mathrm{~min}$. This result is in accordance with Leung et al.(2012) who observed that after five minutes of exposure to recommended concentrations of hydrogen peroxide $(0.017 \%$ to $8.75 \%)$ during clinical disinfection, microbial cells remain intact and alive.

In conclusion, for disinfection of tilapia eggs, iodophor treatment at $10 \mathrm{ppm}$ for $15 \mathrm{~min}$ significantly reduced TBC and TFC by $\geq 4 \log _{10}$ reductions but failed to achieve complete disinfection.Although hatchability percentage between control and $10 \mathrm{ppm}$ has no significant difference but the significant decrease in TBC and TFC recommend the use of disinfectant for the health of fish larvae after hatching. For disinfection of hatchery tools, $1 \%$ Halamid $^{\circledR}$ for 10 min and $1 \%$ Virkon $S^{\circledR}$ for 15 minwere the most effective disinfectants with $100 \% \log _{10}$ reduction for both TBC and TFC.

\section{References}

Apha (American Public Health Association, American Water Works Association and Water Environment Federation) (1998): Standard Methods for the examination of water and waste water, $20^{\text {th }}$ ed., Washington, DC, USA.

Atanasov A., Rusenova N., Staykov Y., Nikolov G., Pavlov A., Stratev D., Raichev E. (2011): Chemical surface disinfection of funnel type fish egg incubators. Journal of Agricultural Science and Technology, 3, 281-284.
Avendano-Herrera, R.; Magarinos, B.; Irgang, R. and Toranzo, A. E. (2006): Use of hydrogen peroxide against the fish pathogen Tenacibaculummaritimum and its effect on infected turbot (Scophthalmusmaximus). Aquaculture 257, 104-110.

Collins, C .H.;Lyne, P. M. and Grange, J. M.(1991): Microbiological Methods. $6^{\text {th }}$ Edition.127-140 Butter Worth-Heinemam Oxford London.

Danner, G. R. and Merrill, P. (2006): Aquaculture Biosecurity: Prevention, Control, and Eradication of Aquatic Animal Disease. Chapter 8.Disinfectants, disinfection, and biosecurity in aquaculture.Scarfe, A.D; C.S. Lee, and P.J. O'Bryen (eds.).World Aquaculture Society/Blackwell Scientific. Hoboken, NJ.

Edrisi, B.; Sadrpoor, A. and Saffari, V. R. (2012): Effects of Chemicals on Vase Life of Cut Carnation (Dianthus caryophyllusL. 'Delphi') and Microorganisms Population in Solution. Journal of Ornamental and Horticultural Plants, 2 (1): 1-11.

Eleraky, N. Z.; Potgieter, L. N. D. and Kennedy, M. A. (2002): Virucidal efficacy of four new disinfectants. J Am AnimHospAssoc 38:231-234.

European Committee for Standardization (CEN), EN 13697:2001 Chemical Disinfectants And Antiseptics - Quantitative Non-porous Surface Test For The Evaluation Of Bactericidal And/or Fungicidal Activity Of Chemical Disinfectants Used In Food, Industrial, Domestic And Institutional Areas - Test Method And Requirements WithoutMechanical Action in phase 2/step2. 2001.

FAO 2011: Food and Agricultural Organization of the United Nations, Fisheries and Aquaculture Department, Global Aquaculture Production Statistics for the year 2011. ftp://ftp.fao.org/Fl/news/GlobalAquaculture ProductionStatistics2011.pdf

GÜngor, Nihal. D. and Yurudu, Nazmiye. $O$. S.(2015): Evaluation of bacterial resistance to Chloramine $\mathrm{T}$ Biocide and effects on Rifampicin Antibiotic Susceptibility as a 
consequence of biocide usage in Cooling System Biofilm including Legionella pneumophila. Istanbul University, Faculty of Science, Department of Biology, Section of Fundamental and Industrial Microbiology $34134 \quad$ Vezneciler, Fatih-_stanbul, Turkey.The Battle Against Microbial Pathogens: Basic Science, Technological Advances and Educational Programs (A. Méndez-Vilas, Ed.).

Harboe, T.; Huse, I. and Øie, G. (1994): Effects of egg disinfection on yolk sac and first feeding stages of halibut (Hippoglossushippoglossus L.) larvae. Aquaculture 119, 157-165.

Jantrakajorn, S.; Wongtavatchai, J.(2015): Egg surface decontamination with bronopol increases larval survival of Nile tilapia, Oreochromisniloticus. Czech J. Anim. Sci. Vol, 60(10), pp: 436-442. Doi: 10.17221/8523-CJAS.

Katharios, P.; Agathaggelou, A.; Paraskevopoulos, S. and Mylonas, C. C. $(2007$ ): Comparison of iodine and glutadehyde as surface disinfectants for red porgy (Pagruspagrus) and white sea bream (Diplodussargussargus) eggs - Aquac. Res. 38: 527-536.

Leung, C. Y.; Chan, Y. C.; Samaranayake, L. P. and Seneviratne, C. J. (2012): Biocide resistance of Candida and Escherichia coli biofilms is associated with higher antioxidative capacities, in $\mathrm{J}$ Hosp Infect., 81(2):79-86.

Macintosh, D.J. and Little, D.C. (1995) Nile tilapia Oreochromisniloticus. In: Bromage, N.R. and Roberts, R.J. (eds) BroodstockManagement and Egg and Larval Quality. Blackwell Science Ltd, Oxford, UK, pp. 277-320.

McDonnell, G., \& Russell, A.D. (1999). Antiseptics and Disinfectants: Activity, Action, and Resistance. Clinical Microbiology Reviews, 12(1): 147-149. Retrieved from http://www.ncbi.nlm.nih.gov/pmc/articles/P MC88911

Overton, J. L.; Bruun, M. S. and Dalsgaard, I. (2010): - Chemical surface disinfection of eggs of Baltic cod, Gadusmorhua L - J. Fish Dis. 33: 707-716.
Peck, M. A.; Buckley, L. J.; O'Bryan, L. M.; Davies, E. J. and Lapolla, A. E. (2004): Efficacy of egg surface disinfectants in captive spawning Atlantic cod GadusmorhuaL. and haddock MelanogrammusaeglefinusL. - Aquac. Res. 35: 992-996

Saleh, M. A. (2007): Freshwater fish seed resources in Egypt. In: BondaReantaso, M.G. (Ed.), Assessment of Freshwater Fish Seed Resources for Sustainable Aquaculture, FAO Fisheries Technical Paper. FAO, Rome, pp. 241-255.

Skjermo, J.; Vadstein, O. (1999): Techniques for microbial control in the intensive rearing of marine larvae. Aquaculture, 177, 333343.

Stuart, K. R.; Keller, M. and Drawbridge, M. (2010): Efficacy of formalin and povidone-iodine disinfection techniques on the eggs of three marine finfish species Aquac. Res. 41: 838-843.

Subasinghe, R. P. and Sommerville C. (1985): Disinfection of Oreochromismossambicus(Peters) eggs against commonly occurring potentially pathogenic bacteria and fungi under artificial hatchery conditions. Aquaculture and Fisheries Managemet,16, p.121-127.

Tendencia, E. A. (2001): Effect of iodine disinfection on the bacterial flora and hatching rate of grouper, Epinepheluscoioides eggs at the cleavage and eyed stages. Bulletin of the European Association of Fish Pathologists 21, 160163.

Varner-Jeffreys, D. W.; Nakamura, I. and Shields, R. J. (2007) :Surface disinfection of Pacific threadfin, Polydactylussexfilis, and amberjack, Seriolarivoliana, eggs Aquac. Res. 38: 605-612.

Wagner E.J., Oplinger R.W., Arndt R.E., Forest A.M. \& Bartley M. (2010) The safety and effectiveness of varioushydrogen peroxide and iodine treatment regimensfor rainbow trout egg disinfection. North American Journalof Aquaculture 72, 34-42.

Wagner, E. J., R. E. Arndt, E. J. Billman, A. Forest, and W. Cavender. 2008. comparison of the efficacy of iodine, formalin, salt, and hydrogen peroxide for 
control of external bacteria on rainbowtrouteggs.North American Journal of Aquaculture 70:118-127.
Yanong, R.P.E. and Erlacher-Reid C., (2012): Biosecurity in Aquaculture part I: An Overview, SRAC Publication No. 4707.

Table (1) Mean \pm SD of water quality parameters and the total microbial countsdetermined during the experiment

\begin{tabular}{|c|c|}
\hline parameters & Mean \pm SD \\
\hline Temperature ${ }^{\circ} \mathrm{C}$ & $28.47 \pm 0.29$ \\
\hline $\mathrm{pH}$ & $7.60 \pm 0.32$ \\
\hline Dissolved oxygen $\mathrm{mg} / \mathrm{l}$ & $5.07 \pm 0.21$ \\
\hline Unionized Ammonia mg/l & $0.19 \pm 0.07$ \\
\hline nitrite- nitrogen $\left(\mathrm{No}_{2}-\mathrm{N} 2\right) \mathrm{mg} / \mathrm{l}$ & $0.05 \pm 0.03$ \\
\hline Total bacterial count $/ \mathrm{ml}$ & $5.97 \pm 0.07$ \\
\hline Total fungal count $/ \mathrm{ml}$ & $5.47 \pm 0.15$ \\
\hline
\end{tabular}

Table (2) Mean \pm SD of total microbial count ( $\left.\log _{10} \mathrm{CFU} / \mathrm{g}\right)$ of tilapia eggs after exposure to different concentrations of iodophor

\begin{tabular}{|c|c|c|c|c|}
\hline \multicolumn{5}{|c|}{ Total bacterial count } \\
\hline Concentration & \multicolumn{4}{|c|}{ Contact time } \\
\hline & 0 min (Control) & $5 \mathrm{~min}$ & $10 \mathrm{~min}$ & $15 \mathrm{~min}$ \\
\hline $10 \mathrm{ppm}^{*}$ & $7.18 \pm 0.86$ & $5.56 \pm 1.42$ & $5.48 \pm 1.36$ & $3.31 \pm 1.30 *$ \\
\hline $50 \mathrm{ppm}$ & $7.18 \pm 0.86$ & $6.75 \pm 0.83$ & $6.68 \pm 0.82$ & $6.62 \pm 0.84$ \\
\hline $100 \mathrm{ppm}$ & $7.18 \pm 0.86$ & $7.05 \pm 0.78$ & $7.01 \pm 0.79$ & $6.96 \pm 0.77$ \\
\hline $150 \mathrm{ppm}$ & $7.18 \pm 0.86$ & $7.09 \pm 0.81$ & $7.06 \pm 0.81$ & $7.02 \pm 0.79$ \\
\hline \multicolumn{5}{|l|}{ Total fungal count } \\
\hline & 0 min (Control) & $5 \mathrm{~min}$ & $10 \mathrm{~min}$ & $15 \mathrm{~min}$ \\
\hline $10 \mathrm{ppm} *$ & $5.63 \pm 1.87$ & $4.89 \pm 1.52$ & $1.00 \pm 0.00$ & $0.69 \pm 0.00 *$ \\
\hline $50 \mathrm{ppm}$ & $5.63 \pm 1.87$ & $5.06 \pm 1.63$ & $4.39 \pm 1.69$ & $4.07 \pm 0.00$ \\
\hline $100 \mathrm{ppm}$ & $5.63 \pm 1.87$ & $5.32 \pm 1.71$ & $5.23 \pm 1.69$ & $5.20 \pm 1.67$ \\
\hline $150 \mathrm{ppm}$ & $5.63 \pm 1.87$ & $5.33 \pm 1.79$ & $5.29 \pm 1.75$ & $5.25 \pm 1.72$ \\
\hline
\end{tabular}

* Values are significantly different at $(\mathrm{P}<0.05)$.

Table (3) Mean \pm SD of TBC $\left(\log _{10} \mathrm{CFU} / \mathrm{cm}^{2}\right)$ after exposure todifferent disinfectants for different contact times on some hatchery tools

\begin{tabular}{|c|c|c|c|c|c|c|c|c|c|c|c|c|}
\hline \multirow{3}{*}{$\begin{array}{c}\text { Type of } \\
\text { disinfectant }\end{array}$} & \multicolumn{12}{|c|}{ Contact time } \\
\hline & \multicolumn{3}{|c|}{$0 \mathrm{~min}$} & \multicolumn{3}{|c|}{5 min } & \multicolumn{3}{|c|}{$10 \mathrm{~min}$} & \multicolumn{3}{|c|}{15 min } \\
\hline & buckets & Dishes & nets & buckets & dishes & nets & buckets & dishes & Nets & buckets & dishes & nets \\
\hline Salt & $\begin{array}{c}8.79 \\
\pm 1.76 \\
\end{array}$ & $\begin{array}{c}8.89 \\
\pm 1.83 \\
\end{array}$ & $\begin{array}{c}8.81 \\
\pm 1.83\end{array}$ & $\begin{array}{c}5.74 \\
\pm 0.80\end{array}$ & $\begin{array}{c}5.81 \\
\pm 0.87 \\
\end{array}$ & $\begin{array}{c}5.74 \\
\pm 0.91\end{array}$ & $\begin{array}{c}5.68 \\
\pm 0.83 \\
\end{array}$ & $\begin{array}{c}5.64 \\
\pm 0.86 \\
\end{array}$ & $\begin{array}{c}5.66 \\
\pm 0.88 \\
\end{array}$ & $\begin{array}{c}5.55 \\
\pm 0.96 \\
\end{array}$ & $\begin{array}{c}4.52 \\
\pm 0.99 \\
\end{array}$ & $\begin{array}{c}5.57 \\
\pm 0.87\end{array}$ \\
\hline $\begin{array}{l}\text { Sunlight } \\
\text { exposure }\end{array}$ & $\begin{array}{r}8.79 \\
\pm 1.79 \\
\end{array}$ & $\begin{array}{c}8.86 \\
\pm 1.82 \\
\end{array}$ & $\begin{array}{c}8.92 \\
\pm 1.84 \\
\end{array}$ & $\begin{array}{c}5.79 \\
\pm 0.84 \\
\end{array}$ & $\begin{array}{c}5.76 \\
\pm 0.90 \\
\end{array}$ & $\begin{array}{c}5.78 \\
\pm 0.86 \\
\end{array}$ & $\begin{array}{c}5.74 \\
\pm 0.86 \\
\end{array}$ & $\begin{array}{c}4.70 \\
\pm 0.88 \\
\end{array}$ & $\begin{array}{c}5.72 \\
\pm 0.86 \\
\end{array}$ & $\begin{array}{c}5.66 \\
\pm 0.88 \\
\end{array}$ & $\begin{array}{c}4.55 \\
\pm 0.88 \\
\end{array}$ & $\begin{array}{c}5.64 \\
\pm 0.89 \\
\end{array}$ \\
\hline Halamid** & $\begin{array}{c}8.77 \\
\pm 1.80\end{array}$ & $\begin{array}{c}8.54 \\
\pm 2.33\end{array}$ & $\begin{array}{c}8.82 \\
\pm 1.86\end{array}$ & $\begin{array}{c}4.64 \\
\pm 0.83\end{array}$ & $\begin{array}{c}4.66 \\
\pm 0.85\end{array}$ & $\begin{array}{c}4.57 \\
\pm 0.84\end{array}$ & $\begin{array}{c}0.00 \\
\pm 0.00 *\end{array}$ & $\begin{array}{c}0.00 \\
\pm 0.00^{*}\end{array}$ & $\begin{array}{c}0.00 \\
\pm 0.00 *\end{array}$ & $\begin{array}{c}0.00 \\
\pm 0.00^{*}\end{array}$ & $\begin{array}{c}0.00 \\
\pm 0.00^{*}\end{array}$ & $\begin{array}{c}0.00 \\
\pm 0.00 *\end{array}$ \\
\hline Virkon S* & $\begin{array}{r}8.82 \\
\pm 1.83 \\
\end{array}$ & $\begin{array}{r}8.85 \\
\pm 1.85 \\
\end{array}$ & $\begin{array}{c}8.87 \\
\pm 1.87\end{array}$ & $\begin{array}{c}5.75 \\
\pm 0.81\end{array}$ & $\begin{array}{c}5.82 \\
\pm 0.88\end{array}$ & $\begin{array}{c}4.74 \\
\pm 0.88\end{array}$ & $\begin{array}{c}4.61 \\
\pm 0.86\end{array}$ & $\begin{array}{c}4.57 \\
\pm 0.79\end{array}$ & $\begin{array}{c}4.58 \\
\pm 0.86\end{array}$ & $\begin{array}{c}0.00 \\
\pm 0.00^{*}\end{array}$ & $\begin{array}{c}0.00 \\
\pm 0.00 *\end{array}$ & $\begin{array}{c}0.00 \\
\pm 0.00^{*}\end{array}$ \\
\hline Aquazix & $\begin{array}{c}8.84 \\
\pm 1.83\end{array}$ & $\begin{array}{c}8.82 \\
\pm 1.86\end{array}$ & $\begin{array}{c}8.87 \\
\pm 1.82\end{array}$ & $\begin{array}{c}5.69 \\
\pm 0.81\end{array}$ & $\begin{array}{c}5.76 \\
\pm 0.90\end{array}$ & $\begin{array}{c}5.80 \\
\pm 0.89\end{array}$ & $\begin{array}{c}5.58 \\
\pm 0.79\end{array}$ & $\begin{array}{c}4.58 \\
\pm 0.79\end{array}$ & $\begin{array}{c}5.63 \\
\pm 0.90\end{array}$ & $\begin{array}{c}4.48 \\
\pm 0.90\end{array}$ & $\begin{array}{c}4.38 \\
\pm 0.79\end{array}$ & $\begin{array}{c}4.61 \\
\pm 0.94\end{array}$ \\
\hline
\end{tabular}

* Values are significantly different at $\mathrm{P}(<0.05)$

** More significant

Table (4) Mean \pm SD of TFC ( $\left.\log _{10} \mathrm{CFU} / \mathrm{cm}^{2}\right)$ after exposure to different disinfectants for different contact times on some hatchery tools

\begin{tabular}{|c|c|c|c|c|c|c|c|c|c|c|c|c|}
\hline \multirow{3}{*}{$\begin{array}{c}\text { Type of } \\
\text { disinfectant }\end{array}$} & \multicolumn{12}{|c|}{ Contact time } \\
\hline & \multicolumn{3}{|c|}{$0 \mathrm{~min}$} & \multicolumn{3}{|c|}{$5 \mathrm{~min}$} & \multicolumn{3}{|c|}{$10 \mathrm{~min}$} & \multicolumn{3}{|c|}{$15 \mathrm{~min}$} \\
\hline & buckets & Dishes & nets & buckets & dishes & nets & buckets & Dishes & nets & Buckets & dishes & nets \\
\hline Salt & $\begin{array}{c}4.43 \\
\pm 0.78\end{array}$ & $\begin{array}{c}4.63 \\
\pm 0.83\end{array}$ & $\begin{array}{c}4.71 \\
\pm 0.85\end{array}$ & $\begin{array}{c}3.64 \\
\pm 0.30\end{array}$ & $\begin{array}{c}3.67 \\
\pm 0.28\end{array}$ & $\begin{array}{c}4.67 \\
\pm 0.86\end{array}$ & $\begin{array}{c}2.53 \\
\pm 0.29\end{array}$ & $\begin{array}{c}2.43 \\
\pm 0.00\end{array}$ & $\begin{array}{c}3.60 \\
\pm 0.87\end{array}$ & $\begin{array}{c}0.00 \\
\pm 0.00\end{array}$ & $\begin{array}{c}0.00 \\
\pm 0.00\end{array}$ & $\begin{array}{c}0.00 \\
\pm 0.00 \\
\end{array}$ \\
\hline $\begin{array}{l}\text { Sunlight } \\
\text { exposure }\end{array}$ & $\begin{array}{c}4.46 \\
\pm 0.77\end{array}$ & $\begin{array}{c}4.39 \\
\pm 0.85\end{array}$ & $\begin{array}{c}4.91 \\
\pm 0.88\end{array}$ & $\begin{array}{c}3.83 \\
\pm 0.44\end{array}$ & $\begin{array}{c}3.71 \\
\pm 0.24\end{array}$ & $\begin{array}{c}4.76 \\
\pm 0.87\end{array}$ & $\begin{array}{c}3.62 \\
\pm 0.32\end{array}$ & $\begin{array}{c}3.60 \\
\pm 0.19\end{array}$ & $\begin{array}{c}4.70 \\
\pm 0.82\end{array}$ & $\begin{array}{c}0.00 \\
\pm 0.00\end{array}$ & $\begin{array}{c}0.00 \\
\pm 0.00\end{array}$ & $\begin{array}{c}0.00 \\
\pm 0.69 \\
\end{array}$ \\
\hline Halamid* & 4.58 & 4.42 & 4.77 & 3.44 & 2.47 & 4.65 & 0.00 & 0.00 & 0.00 & 0.00 & 0.00 & 0.00 \\
\hline
\end{tabular}


